Öneç, Onur Esbah; Literature Search: Birgül Öneç, Ali Ümit Esbah; Writing: Birgül Öneç, Ali Ümit Esbah.

Conflict of Interest: The authors of this paper have no conflicts of interest, including specific financial interests, relationships, and/or affiliations relevant to the subject matter or materials included.

\section{References}

1. Schniederjan SD, Osunkoya AO. Lymphoid neoplasms of the urinary tract and male genital organs: a clinicopathological study of 40 cases. Mod Pathol 2009;22:1057-1065.

2. Stamatiou K, Pierris N. Lymphoma presenting as cancer of the glans penis: a case report. Case Rep Pathol 2012;2012:948352.

3. Gentile G, Broccoli A, Brunocilla E, Schiavina R, Borghesi M, Romagnoli D, Bianchi L, Derenzini E, Agostinelli C, Franceschelli A, Colombo F, Zinzani $\mathrm{PL}$. An isolated penile mass in a young adult turned out to be a primary marginal zone lymphoma of the penis. A case report and a review of literature. Anticancer Res 2013;33:2639-2642.
4. Gong Z, Zhang $Y$, Chu $H$, Lian $P$, Zhang L, Sun $P$, Chen J. Priapism as the initial symptom of primary penile lymphoma: a case report. Oncol Lett 2014;8:1929-1932.

5. Chu L, Mao W, Curran Vikramsingh K, Liu X, Qiu HM, Zheng JH, Wang Y, Yu GP, Xu Q. Primary malignant lymphoma of the glans penis: a rare case report and review of the literature. Asian J Androl 2013;15:571-572.

6. Karki K, Mohsin R, Mubarak M, Hashmi A. Primary Non-Hodgkin's lymphoma of penis masquerading as a non-healing ulcer in the penile shaft. Nephrourol Mon 2013;5:840-842.

7. Wang GC, Peng $B$, Zheng JH. Primary penile malignant lymphoma: report of a rare case. Can Urol Assoc J 2012;6:E277-279.

8. Marks D, Crosthwaite A, Varigos G, Ellis D, Morstyn G. Therapy of primary diffuse large cell lymphoma of the penis with preservation of function. $J$ Urol 1988;139:1057-1058.

9. Kim HY, Oh SY, Lee $\mathrm{S}$, Lee DM, Kim SH, Kwon HC, Hong SH, Yoon JH, Kim HJ. Primary penile diffuse large B cell lymphoma treated by local excision followed by rituximab-containing chemotherapy. Acta Haematol 2008;120:150-152.

10. Jabr Fl. Recurrent lymphoma presenting as a penile ulcer in a patient with AIDS. Dermatol Online J 2005;11:29.

\title{
Successful Treatment of Disseminated Fusariosis with the Combination of Voriconazole and Liposomal Amphotericin B
}

\author{
Vorikonazol ve Lipozomal Amphoterisin B ile Başarıyla Tedavi Edilen Dissemine \\ Fusariosis Olgusu
}

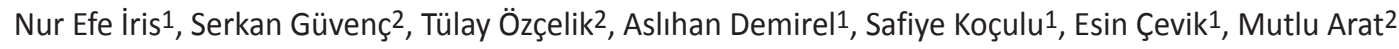 \\ 1istanbul Bilim University Faculty of Medicine, Department of Infectious Diseases and Clinical Microbiology, Istanbul, Turkey \\ 2istanbul Bilim University Faculty of Medicine, Department of Hematology, istanbul, Turkey
}

To the Editor,

Fusarium species are important causes of disseminated infections in patients with prolonged, severe neutropenia. Clinical presentation includes refractory fever, skin lesions, and sinopulmonary infections [1,2]. Disseminated Fusarium infection (DFI) carries a poor prognosis, which is related to the angiotropism of Fusarium and its capacity for adventitious sporulation in tissues [3] and resistance to many antifungal agents [4].

Here we report a hematopoietic stem cell transplant (HSCT) recipient with acute myeloid leukemia (AML) and disseminated fusariosis who was successfully treated using both liposomal amphotericin B and voriconazole.
A 24-year-old male patient underwent allogeneic HSCT from his HLA-matched brother for AML in the first remission. At 21 months after HSCT he had extramedullary relapse with a mass over his humerus. He received radiotherapy plus the FLAG-IDA salvage regimen. After 4 months, medullary relapse occurred.

When he was hospitalized for the medullary relapse, he received clofarabine with ARA-C, which caused severe neutropenia and fever. According to in-house protocol for neutropenia, piperacillin-tazobactam was initiated. However, on the third day, he was still febrile and neutropenic, so treatment was changed to meropenem and 2 days later amikacin was added. Because of hypotension, we broadened the spectrum with vancomycin. He was still febrile and he had rectal carbapenemresistant Klebsiella pneumoniae colonization. Antibiotherapy was reordered with colistin plus meropenem and vancomycin. 
According to thorax computed tomography findings that showed a nodule on the base of the left lung and sphenoidal sinusitis, $3 \mathrm{mg} / \mathrm{kg}$ liposomal amphotericin B was added empirically to his treatment. On follow-up, new papular and nodular skin lesions appeared on his face, head, arms, legs, feet, and anteriorposterior trunk. Some of these papules had central necrosis and eschar formations on his feet (Figure 1). These papules and especially the nodules were extremely painful, and he also had myalgia. Blood cultures revealed Fusarium solani by the VITEK system and MALDI-TOF. The diagnosis of DFI was established and we decided to augment the antifungal therapy on the seventh day by adding intravenous voriconazole as Fusarium is a resistant pathogen and the prognosis is especially poor in neutropenic patients. There were no antifungal susceptibility test results for amphotericin B or voriconazole. The skin lesions were not biopsied or cultured. Five days later his skin lesions began to resolve and on the sixth day of combined antifungal therapy his fever subsided. He was neutropenic at the time and neutrophil levels resolved 5 days later when he was afebrile. Clinical improvement was evident 5 days before the resolution of neutropenia. Parenteral antifungal treatment was continued for 21 days and the patient was discharged on oral voriconazole treatment. After combined antifungal therapy, blood cultures obtained on the fifth day were negative.

We added voriconazole to the antifungal treatment of this patient because disseminated fusariosis has a very poor prognosis. Some investigators have stated that antifungal therapy is rarely effective and recovery depends on neutrophil recovery, but we achieved effective control of fusariosis with combined antifungal therapy before neutrophil recovery $[5,6,7,8,9,10]$.

In conclusion, using combination therapy such as amphotericin $\mathrm{B}$ and voriconazole may be considered as early as possible in patients who are not responding to antifungal monotherapy.

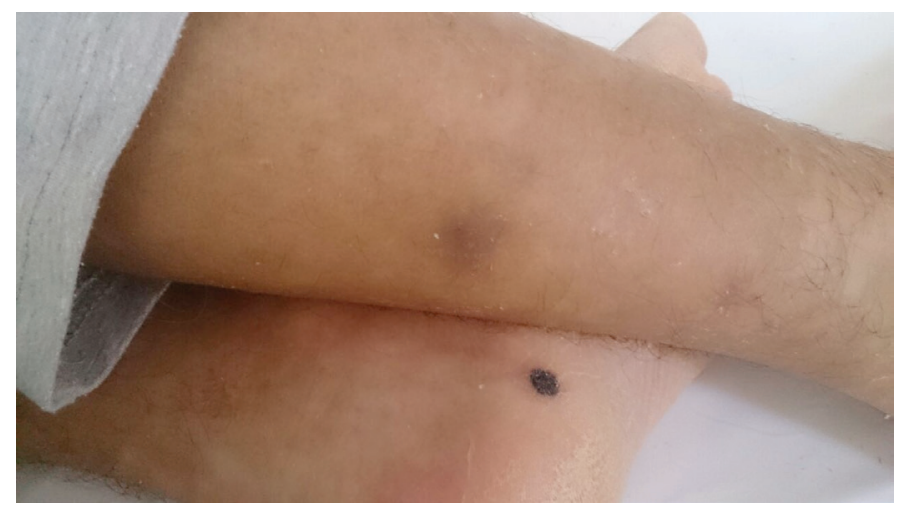

Figure 1. Eschar formation on the foot and papules over the leg.
Keywords: Invasive fungal infection, Fusariosis, Combined antifungal treatment, Lyposomal amphotericin B, Voriconazole, Acute myeloid leukemia

Anahtar Sözcükler: İnvazif mantar enfeksiyonu, Fusariosis, Kombine antifungal tedavi, Lipozomal amfoterisin B, Vorikonazol, Akut myeloid lösemi

\section{Authorship Contributions}

Concept: Nur Efe İris; Design: Nur Efe İris, Mutlu Arat; Data Collection or Processing: Nur Efe İris, Serkan Güvenç; Analysis or Interpretation: Nur Efe İris, Tülay Özçelik, Safiye Koçulu, Aslıhan Demirel, Esin Çevik; Literature Search: Nur Efe İris; Writing: Nur Efe İris, Serkan Güvenç.

Conflict of Interest: The authors of this paper have no conflicts of interest, including specific financial interests, relationships, and/or affiliations relevant to the subject matter or materials included.

\section{References}

1. Nelson PE, Dignani MC, Anaissie EJ. Taxonomy, biology and clinical aspects of Fusarium species. Clin Microbiol Rev 1994;7:479-504.

2. Dignani MC, Anaissie E. Human fusariosis. Clin Microbiol Infect 2004;10(Suppl 1):67-75.

3. Liu K, Howell DN, Perfect JR, Schnell WA. Morphologic criteria for the preliminary identification of Fusarium, Paecilomyces, and Acremonium species by histopathology. Am J Clin Pathol 1998;109:45-54.

4. Jossi M, Ambrossioni J, Macedo-Vinas Garbino J. Invasive fusariosis with prolonged fungemia in a patient with acute lymphoblastic leukemia; case report and review of the literature. Int J Inf Dis 2010;14:e394-e356.

5. Consigny $\mathrm{S}$, Dhedin N, Datry A, Choquet S, Leblond V, Chosidow 0. Successful voriconazole treatment of disseminated Fusarium infection in an immunocompromised patient. Clin Infect Dis 2003;37:311-313.

6. Bodey G, Boutati EL, Anaissie E. Fusarium, a significant emerging pathogen in patients with hematologic malignancy: ten years of experience at a cancer center and implications for management. Blood 1997;3:999-1008.

7. Velasso E, Martis C, Nucci M. Successful treatment of catheter related fusarial infection in immunocompromised children. Eur J Clin Microbiol Infect Dis 1995;14:697-699.

8. Dobougogne A, de Hoog S, Lozniewski A, Machounant M. Amphotericin $B$ and voriconazole susceptibility profiles for the Fusarium solani species complex: comparison between the E-test and CLSIM38A2 microdilution methodology. Eur J Clin Microbiol Infect Dis 2012;31:615-618.

9. Compo $M$, Lewis $R E$, Kontoyiannis DP. Invasive fusariosis in patients with hematologic malignancies at a cancer center: 1998-2009. J Infect 2010;60:331-337.

10. Avelino-Silva VI, Ramos JF, Leal FE, Tastograssa L, Novis YS. Disseminated Fusarium infection in autologous stem cell transplant recipient. Braz J Infect Dis 2015;19:90-93.
Address for Correspondence/Yazışma Adresi: Nur EFE IRIS, M.D.,

Istanbul Bilim University Faculty of Medicine, Department of Infectious

Diseases and Clinical Microbiology, Istanbul, Turkey

Phone : +90212361 8800

E-mail : nurefeiris@yahoo.com
Received/Geliş tarihi: March 25, 2016

Accepted/Kabul tarihi: June 17, 2016

DOI: 10.4274/tjh.2016.0128 